https://doi.org/10.30910/turkjans.471341

\begin{tabular}{c}
\hline TÜRK \\
TARIM ve DOĞA BILIMLERI \\
DERGISI \\
\hline \hline
\end{tabular}

\title{
Hatay İlinde Tıbbi ve Aromatik Bitki Pazarlayan İşletmelerin Değerlendirilmesi ve Aktarların Sosyo-Ekonomik Analizi
}

Hasan ASIL*, Selim TAŞGIN

Hatay Mustafa Kemal Üniversitesi Altınözü Tarım Bilimleri Meslek Yüksekokulu Tıbbi ve Aromatik Bitkiler Programı, Hatay, Türkiye

*Sorumlu yazar: hasanasil@mku.edu.tr

Geliş Tarihi: 13.07.2018

Düzeltme Geliş Tarihi: 25.09.2018

Kabul Tarihi: 01.10.2018

\section{Ozet}

Günümüzde modern tıp ne kadar gelişirse gelişsin bitkisel tedavi yöntemleri yaygın olarak kullanılmaya devam etmektedir. Bunun için de genellikle yerleşim bölgelerinde bulunan "Baharatçı Dükkanı" ya da "Aktar dükkanı" olarak adlandırılan yerlerden hastalıkların tedavisi için tıbbi ve aromatik bitkiler alınmaktadır. Bitkisel tedavinin yaygın olarak kullanılmasında bu işin ticaretini yapan aktarlar önemli bir role sahiptir. Bu çalışmada Hatay ili Antakya merkezindeki aktarlarda satılan tıbbi ve aromatik bitkilerin değerlendirilmesi ve aktarların sosyo-ekononil analizlerinin ortaya konulması amaçlanmıştır. Ayrıca, aktarların sosyo- ekonomik analizi, tıbbi ve aromatik bitkilerin kullanım yöntemleri değerlendirilmesi yapılmıştır. Bununla birlikte ürünlerin muhafaza şekilleri, satış miktarları değerlendirilmiştir. Aktarların \%89'unun erkek, \%47'sinin 40 yaş üzeri ve \%39'nun lise mezunu olduğu, \%84'ü mesleği ustasından veya babasından öğrendiğini ve \%88'inin iş deneyimi 6 yıl ve daha fazla olduğu sonucuna ulaşılmıştır. Aktarlardan elde edilen bulgulara göre oğul otu (\%89), mercan köşk (\%87) zerdaçal (\%82) daha çok tedavi amaçlı kullanılırken, yaban mersini (\%69), böğürtlen (\%64), reyhan (\%47) gıda olarak kullanılmaktadır. Baharat olarak daha çok defne bitkisi (\%40), çörek otu (\%38) kullanılırken, kozmetik sektöründe daha çok avakado yaprağı (\%25), karaçalı (\%17) ve rezene (\%10) kullanılmaktadır.

Anahtar kelimeler: Aktar, Antakya, tıbbi ve aromatik bitkiler, sosyo-ekonomik analiz.

\section{Evaluation of Medicinal and Aromatic Plant Market in Hatay Province and Socio-Economic Analysis of Aktar's}

\begin{abstract}
Today, however, as the modern medicine develops, the herbal treatment methods continue to be widely used. To this end, medicinal and aromatic plants are being used for the treatment of diseases, usually in the so-called "Spice Shop" or "Aktar shop" in the settlement areas. Aktar's that make trade in this business play an important role in the widespread use of herbal remedies. This study was carried out to evaluate the medicinal and aromatic plants sold in the districts of Antakya, Hatay province and to reveal the socio-economic analysis of the transplants. In this study, the socio-economic structure of the Aktar, the methods of using medical and aromatic plants were studied. Also the storage forms, sales quantities were evaluated. It was concluded that $89 \%$ of the transfers were male, $47 \%$ were above 40 years old and $39 \%$ were high school graduates, $84 \%$ learned from the master or his father and $88 \%$ had 6 years or more work experience. According to the findings obtained from the herbs (89\%) and coral pavilion (87\%) were used for treatment purposes, while bilberry (69\%), dewberry (64\%) and basil (47\%) were used as food. While more daphne (40\%) and nigella $(38 \%)$ are used as spices, alligator pear leaves $(25 \%)$, paliurus $(17 \%)$ and fennel $(10 \%)$ were used in cosmetics sector.
\end{abstract}

Key words: Aktar, Antioch, medical and aromatic plants, socio-economic analysis. 


\section{Giriş}

Türkiye üç bitki coğrafyası üzerinde bulunmasından dolayı geniş bir bitki varlığına sahiptir. Bunlar Akdeniz, Avrupa-Sibirya ve IranTuran bölgeleridir. Bu bölgeler kendi içlerinde doğal biyolojik çeşitliliğe sahiptir. Antakya'nın da içinde bulunduğu Akdeniz Bitki Coğrafyası bölgesi, Akdeniz bölgesinden başlayarak Ege ve Marmara bölgeleri ve Batı Trakya'yı kapsamaktadır. Bu bölgenin özellikle yüksek kesimlerinde endemik bitki çeşitliliği oldukça yüksektir. Özellikle de Toros dağları diğer yerlere göre daha çok endemik bitki çeşitliliği bulunmaktadır. Türkiye'de en fazla endemik bitki türü bulunan bölgeler Toroslar (özellikle orta Toroslar), Amanos, Kaz dağları, Anti Toroslar, Kuzey Geçit Bölgesi, Doğu Anadolu'nun Kuzey ve Güneyi ile Tuz Gölü civarıdır (Karagöz ve ark. 2010; Tan, 2010).

Bitkilerin tedavi edici özelliği insanlık tarihi kadar eskidir. Insanlar, sağıklı yaşayabilmek ve hastalıkları tedavi etmek için bitkilerin tedavi edici özelliğinden faydalanmışlardır. Halk hekimliği uygulamalarında bitkisel tedavi genellikle deneme yanılma yöntemleri ile günümüze kadar gelmiştir. Modern tıpta ise hastalıkların tedavisinde bitkilerden elde edilen ilaçlar kullanılmaktadır (Faydaoğlu ve Sürücüoğlu, 2011).

Bitkisel tıbbın kökenine ait ilk yazılı belge olan M.Ö.3000 yıllarına ait Ninova Tabletleri, Mezapotamya' da bitkisel ve hayvansal ilaçlarla tedavilerin mevcut olduğunu kanıtlamaktadır. Bitkisel tıp, Çin, Hint, Mısır uygarlıklarında bitkilerin tedavide kullanılmış ve halen devam etmektedir. Modern tıbbın kurucusu sayılan Hipokrat'a ait kitaplarda 400'e yakın bitkisel ilaç anlatılmıştır (Anonim, 2018).

Amerika'da Ulusal Kanser Enstitüsü'nün, yapmış olduğu araştırmalarda: satılan ilaçların \%40'ı bitkisel kökenlidir. Amerika'da reçeteli satılan ilaçların \%50'si doğal ilaçlardan oluşturmaktadır. Almanya'da ise reçeteli satılan ilaçlar içerisinde en çok satılan 7 ilacın lisanslı Hypericum perforatum (Sarı kantaron) preparatıdır. Bu da özellikle gelişmiş ülkelerde bitkisel preparat kullanımının yoğun olduğunu göstermektedir. Türkiye'de ise bitkisel ilaç kullanan hastalar daha çok aktarlardan aldıkları bitki parçalarından kendileri hazırlamaktadırlar. Herhangi bir uzmana danışmadan kullanmaktadırlar (Anonim, 2018).

Tarihte bitkilerle ilgili en eski reçetelerden biri Hititlere aittir. Ayrıca Sümerlerden ve Mısırlardan kalan tablet ve yazıtlarda da tıbbi bitkiler hakkında önemli bilgiler bulunmaktadır. İlaçlar ve tedavi ile ilgili bulunan papirüslerde 77 bitkisel, hayvansal ve madensel drog ve 800 den fazla bitkisel ilaç tarifi bulunmaktadır. Bu tariflerde en çok üzüm, terementi, incir, keten tohumu, çiğdem, hardal, dağ soğanı, Acımarul, ardıç meyvesi, banotu, hintyağı, centiyane, kişniş, mürver, nar kabuğu, pelinotu, sakız, sarısabır, soğan ve tarçının adı geçmektedir. Osmanlı döneminde hastalıkların tedavisinde hekimlerin ya da aktarların hazırladığı karışımlarla tedavi yapılıyordu. 1868 yılında İstanbul'da 45 eczaneye karşılık 2000 aktar bulunması, aktarların halk sağlığındaki önemini belirleyen bir kanıttır (Bayramoğlu ve Toksoy, 2008).

İstanbul, Bizanslılar döneminde 6. Yüzyıldan itibaren baharat ve drog ticaretinin merkezi konumuna gelmiştir. Uzak Doğu'nun drog ve baharatı (Biber, karanfil, küçük hindistancevizi, kafur, misk, sarısabır, tarçın, zencefil ve diğerleri) eşek, katır veya deve kervanları ile Antakya, İskenderun veya Trabzon limanlarına gelir ve buradan da gemiler ile İstanbul'a nakledilirdi (Baytop, 1990).

Anadolu insanının günümüzde, modern tıbbın tanı ve tedavisini uygulamakla birlikte, bazı hastalıkların tedavisi için yerleşim bölgelerinde bulunan "Baharatçı dükkanı" ya da "Aktar dükkanı" olarak adlandırılan ticarethanelere başvurup bitkiler satın alması bu geleneksel halk tıbbı kültürünün hala devam ettiğinin bir göstergesidir (Özbek, 2005; Sarışen ve Çalışkan, 2005; Koçtürk ve ark., 2009; Açıkgöz ve ark., 2012; Altay ve ark., 2015).

Hatay ile baharat kültürünün merkezi konumunda olması nedeniyle çok sayıda aktar ve baharatçı dükkânını içerisinde barındırmaktadır. Hatay ili genelinde 49 aktar bulunmaktadır. Bu aktarların büyük bir kısmı Antakya merkezde uzun çarşı içerisinde bulunan baharatçılar çarşısında yer almaktadır. Bu çalışma, Antakya merkezindeki aktarlara yerinde ziyaret yapılarak aktarların yapısal analizini ortaya koymak ve aktarlardaki satılan tıbbi ve aromatik bitkileri pazarlama yapısını değerlendirmek amacıyla yapılmıştır.

\section{Materyal ve Yöntem}

Hatay ili genelinde 49 aktar bulunmaktadır. Bu aktarların büyük bir kısmı Antakya ilçesinde yer alan uzun çarşı içerisindeki baharatçılar çarşısında yer almaktadır. Antakya merkezde esas itibariyle 19 adet aktar bulunmakta ve bazı aktarların şubeleriyle birlikte aktar sayısı 25 adede çıkmaktadır. Çalışmada verileri toplamak için 2018 yılı Şubat-Haziran aylarında aktarlarla yüz yüze görüşerek 19 adet anket yapılmıştır. Aktarlarda yetkili kişilerle tıbbi ve aromatik bitkilerin en çok tercih edilenleri, bu bitkilerin kullanım şekilleri ve 
temini, yine bu bitkilerin faydaları ve hastalıklara göre değerlendirilmesi, tıbbi ve aromatik bitkiler hakkında hangi kaynaklardan yararlandıkları, aktarların kendi tecrübeleri ve müşteri taleplerine göre hangi bitkinin hangi hastalıklarda tercih edildiği hakkında bilgiler alınmıştır.

Ayrıca aktarların demografik bilgileri, mesleki deneyimi, mesleği öğrenme şekilleri, meslek hakkındaki bilgi kaynakları, ürünleri tedarik şekilleri, üreticiden ve toplayıcıdan aldıktan sonra yapılan işlemler, ürün muhafaza şekilleri, ürünlerin satış miktarı, şekilleri ve aktarların sosyo-ekonomik analizleri ortaya konmuştur. Aktarlardan elde edilen bilgi ve bulguların tartışma bölümünde ayrı ayrı değerlendirmesi yapılmıştır.

\section{Bulgular ve Tartışma}

Hatay sınırları içinde 250'nin üzerinde endemik, 2400'den fazla bitki taksonu yayılış göstermekte olup, 180'nin üzerinde bitki türü ilk kez Hatay ilinden toplanıp bilim dünyasına tanıtılmıştır. Birçok bitki türü, adını Antakya'dan ve Hatay'da bulunan Amanos dağından almıştır. Bunlardan bir kaçı; (Centaurea antiochia, Antakya Peygamberçiçeği), (Gagea antakiensis, Antakya).
Hatay ilinde yayılış gösteren 157 bitki türünün nesli ise tehlike altındadır (Ocak ve ark., 2014).

Hatay ilinde tıbbi ve aromatik bitkiler genellikle doğadan toplamayla karşılanmaktadır. Hatay ilinde en fazla toplamanın yapıldığı ilçeler Yayladağı, Altınözü ve Samandağ'dır. Hatay ilinde önemli tıbbi ve aromatik bitkilerin başında defne bitkisi gelmektedir. Defne bitkisi hem üretim alanı ve miktarı bakımından hem de sanayi ve ticaret yönünden önemli bir bitkidir. Hatay ilinin toplam orman alanının \%40'ını oluşturmaktadır. Bunun yanı sıra, sumak, kekik, adaçayı ve biberiye gibi bitkilerde yaygın olarak bölgenin ekolojisinde yer almaktadır (Gül ve Çelik, 2016).

\section{Aktarlardaki satılan tıbbi ve aromatik bitkilerin değerlendirilmesi \\ Antakya aktarlarında genel olarak talep edilen bitkiler}

Aktarlarda genel olarak tercih edilen bitkilerin neler olduğu sorulmuştur. Alınan verilere göre bu bitkiler Çizelge 1'de gösterilmiştir. Aktarlarda satılan tıbbi ve aromatik bitkilerin hem Dünya'da hem de Türkiye'de önemli olan bitkiler olduğu

Çizelge 1. Antakya aktarlarında genel olarak talep edilen tıbbi ve aromatik bitkiler.

\begin{tabular}{llll}
\hline Adaçayı & Hindiba & Civanperçemi & Keçiboynuzu \\
Kekik & Kazayağı & Sığır kuyruğu & Çörekotu \\
Nane & Kuzukulağı & Oğul otu-Melisa & Defne \\
Gülhatmi & Sütleğen & Reyhan & Rezene \\
Kişniş & Dereotu & Keten tohumu & Ardıç \\
Papatya & Sarımsak & Eşek turbu & Sumak \\
Ihlamur & Avakado yaprağı & Nar çiçeği & Kakule \\
Kuşburnu & Menengiç & Reyhan/fesleğen & Pelin otu \\
Kantaron & Andız & Biberiye & Karaçalı \\
Ekinezya & Böğürtlen & Zerdeçal & Meyan kökü \\
Isırgan & Yaban mersini & Sabun otu & Anason \\
Ebegümeci & Zencefil & Kadın tuzluğu & Kimyon \\
Efelek & Mercanköşk & Kebere & Haşhaş \\
\hline
\end{tabular}

\section{Antakya ili aktarlarında en çok satışı yapılan tıbbi ve aromatik bitkiler}

Aktarlarda en çok satışı yapılan tıbbi ve aromatik bitkiler sorulmuş ve Çizelge 2'de gösterilmiştir. Aktarlar tarafından en çok satışı yapılan tıbbi ve aromatik bitkilerin sıralaması yapılmıştır. Bu sıralamaya göre en çok satışı yapılan bitkilerin başında adaçayı, nane, kekik ve zencefil gibi genellikle soğuk algınlığı ve gribal enfeksiyonlarda kullanılan bitkilerdir.

\section{Aktarlarda satışı yapılan tıbbi ve aromatik bitkiler kullanım şekilleri}

Aktarlarda satılan bitkilerin kullanım şekilleri değerlendirmek amacıyla tıbbi ve aromatik bitkileri kullanım şekilleri olan; tedavi, gıda, hem tedavi hem gıda, baharat ve kozmetik gibi kullanım şekillerine cevaplar alınmış ve değerlendirilmesi Çizelge 3'de verilmiştir. Aktarlarda satışı yapılan bitkiler genellikle tedavi, gıda ve hem tedavi hem gıda olarak tercih edilmektedir. Baharat ve kozmetik amaçlı kullanım daha az tercih edilmektedir. Ayrıca bir bitkinin birçok faydası olduğundan tüm kullanım şekillerinde tercih edilmektedir. Örneğin kekik bitkisinin kullanım şekillerine baktığımızda tedavi, gıda, hem tedavi gıda, baharat ve kozmetik amaçlı kullanılmaktadır. $\mathrm{Bu}$ yüzden tıbbi ve aromatik bitkilerinin kullanım şekilleri tercihe göre farklılık gösterdiği için bu bitkileri kesin hatlarla ayırmak oldukça güçtür. 
Çizelge 2. Aktarlarda en çok satışı yapılan tıbbi ve aromatik bitkiler.

\begin{tabular}{clclll}
\hline No & Tıbbi bitki adı & No & Tıbbi bitki adı & No & Tıbbi bitki adı \\
\hline 1 & Adaçayı & 8 & Keçi boynuzu & 15 & Kantaron \\
2 & Nane & 9 & Civan perçemi & 16 & Ihlamur \\
3 & Kekik & 10 & Ihlamur & 17 & Papatya \\
4 & Zencefil & 11 & Çörek otu & 18 & Yaban mersini \\
5 & Zerdeçal & 12 & Kimyon & 19 & Reyhan/fesleğen \\
6 & Karabiber & 13 & Oğul otu - melisa & 20 & Böğürtlen \\
7 & Melisa & 14 & Kuşburnu & & \\
\hline
\end{tabular}

Çizelge 3. Kullanım şekillerine göre aktarlarda en çok tercih edilen tıbbi ve aromatik bitkiler.

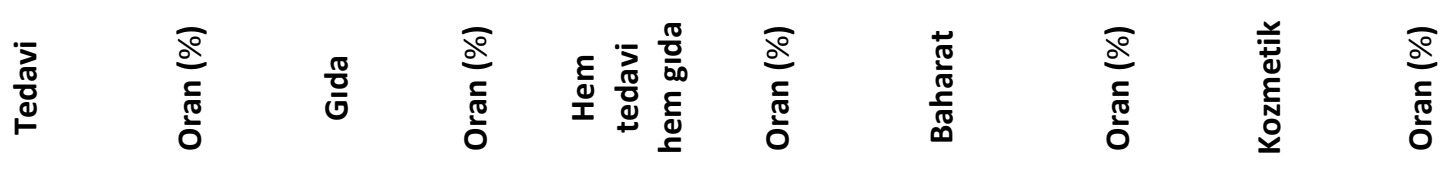

\begin{tabular}{|c|c|c|c|c|c|c|c|c|c|}
\hline $\begin{array}{l}\text { Oğulotu / } \\
\text { Melisa }\end{array}$ & 89 & $\begin{array}{l}\text { Yaban } \\
\text { mersini }\end{array}$ & 69 & Nane & 47 & Defne & 40 & $\begin{array}{l}\text { Avakado } \\
\text { yaprağı }\end{array}$ & 25 \\
\hline Kuşburnu & 79 & $\begin{array}{l}\text { Reyhan/ } \\
\text { fesleğen }\end{array}$ & 47 & Sarımsak & 47 & Çörekotu & 38 & Kuşburnu & 5 \\
\hline Kantaron & 74 & $\begin{array}{l}\text { Kadın } \\
\text { tuzluğu }\end{array}$ & 47 & Kekik & 42 & Kekik & 16 & Sarımsak & 6 \\
\hline Ihlamur & 74 & Böğürtlen & 64 & Kimyon & 47 & Nane & 11 & $\begin{array}{l}\text { Reyhan / } \\
\text { Fesleğen }\end{array}$ & 6 \\
\hline Papatya & 74 & Kişniş & 32 & Anason & 47 & Biberiye & 12 & Kişniş & 5 \\
\hline Ekinezya & 74 & Sarımsak & 35 & Fesleğen & 31 & Gülhatmi & 5 & Efelek & 6 \\
\hline Gülhatmi & 74 & Sumak & 31 & Kişniş & 21 & Hindiba & 6 & Rezene & 10 \\
\hline Zerdeçal & 82 & Nar çiçeği & 33 & Sumak & 25 & Civanperçemi & 6 & $\begin{array}{l}\text { Oğul otu } \\
\text { Melisa }\end{array}$ & 6 \\
\hline Menengiç & 76 & Rezene & 50 & $\begin{array}{l}\text { Reyhan/ } \\
\text { fesleğen }\end{array}$ & 18 & Kuşburnu & 5 & Karaçalı & 17 \\
\hline Isırgan & 81 & Kantaron & 21 & Ekinezya & 11 & Haşhaş & 33 & & \\
\hline Meyan kökü & 87 & Ihlamur & 21 & Gülhatmi & 11 & & & & \\
\hline Mercanköşk & 87 & $\begin{array}{l}\text { Avakado } \\
\text { yaprağı }\end{array}$ & 25 & Hindiba & 12 & & & & \\
\hline Zencefil & 62 & Çörekotu & 25 & Efelek & 13 & & & & \\
\hline Civanperçemi & 81 & Nane & 21 & Kazayağı & 13 & & & & \\
\hline Adaçayı & 67 & Kekik & 21 & Kantaron & 5 & & & & \\
\hline Sığır kuyruğu & 86 & Papatya & 16 & Papatya & 5 & & & & \\
\hline Dereotu & 80 & Ekinezya & 16 & Menengiç & 6 & & & & \\
\hline Sütleğen & 86 & Menengiç & 18 & Adaçayı & 6 & & & & \\
\hline Kuzukulağı & 80 & Isırgan & 19 & Kuzukulağı & 7 & & & & \\
\hline Hindiba & 71 & Ardıç & 43 & Keçiboynuzu & 7 & & & & \\
\hline
\end{tabular}

\section{Aktarların sosyo-ekonomik analizi Aktarların demografik bilgileri}

Aktarların demografik bilgilerini öğrenmek amacıyla aktarlara yaş aralıkları, cinsiyet, eğitim durumları ve gelir durumları hakkında sorular sorulmuştur ve bu soruların cevapları Şekil 1'de gösterilmiştir. Aktarların cinsiyetlerine bakıldığında \%89'u erkek, \%11'i bayandır. Yaş aralıkları değerlendirildiğinde aktarların \%47'si 40 yaş ve üzeri, $\% 5$ 'i ise $0-20$ yaş aralığında olduğu belirlenmiştir. Eğitim durumlarına bakıldığında ise \%39'unun lise mezunu \%22'sinin ise lisans mezunu olduğu görülmektedir. İşletmelerin gelir durumlarına bakıldığında ise \%47'sinin 1601-2500 TL arasında olduğu görülmektedir.

\section{Aktarların mesleki deneyimleri}

Aktarların mesleki deneyimlerini nasıl edindikleri hakkında bilgileri öğrenmek amacıyla mesleği öğrenme şekilleri, iş deneyimleri ve meslek hakkında bilgi edinme 
şekilleriyle ilgili sorular sorulmuş ve değerlendirme Şekil 2'de gösterilmiştir. Aktarların \%84'i işi ustasından yada babasından öğrendiğini belirtmiştir. Ayrıca aktarların \%88'inden fazlasının 6 yıldan daha fazla deneyime sahip olduklarını

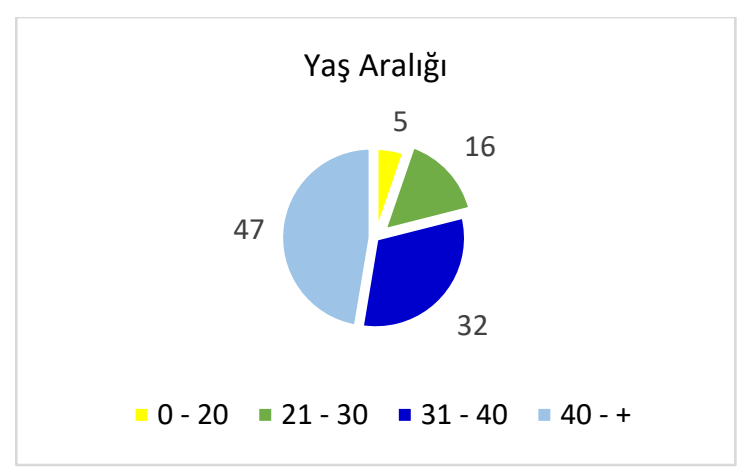

(a)

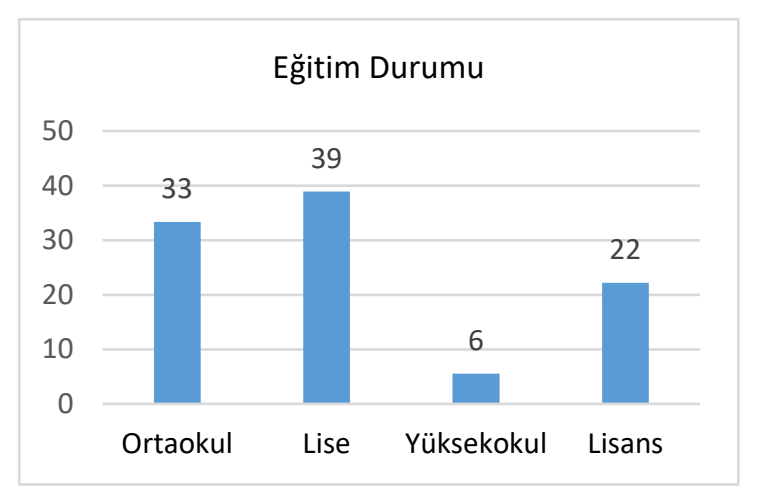

(c)

Şekil 1. Aktarların demografik bilgileri.

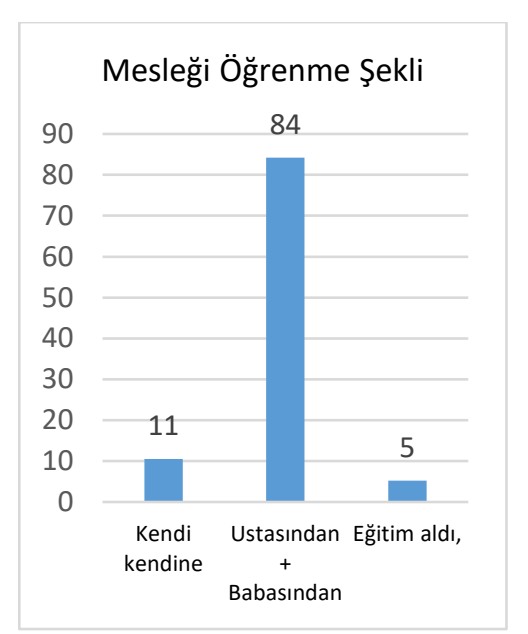

(a)

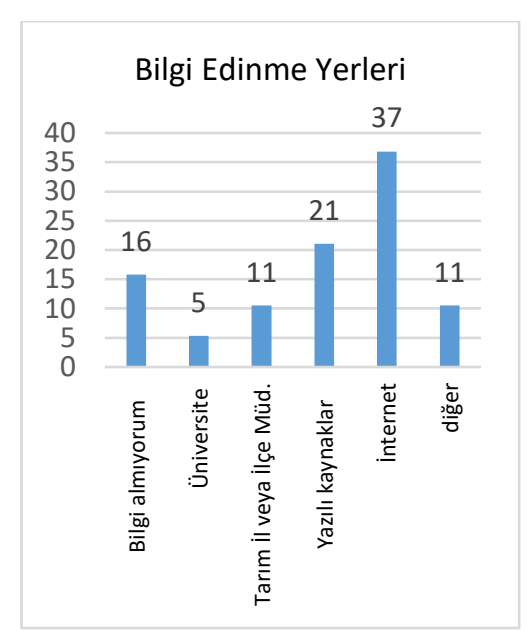

(b) belirtmişlerdir. Aktarlar bilgi edinme şekillerinde en fazla internet yoluyla bilgi edindikleri görülmektedir. Internet yoluyla bilgi edinmeyi yazılı kaynaklar takip etmektedir. Herhangi bir kaynağa başvurmayan aktar oranı ise \%16'dır.

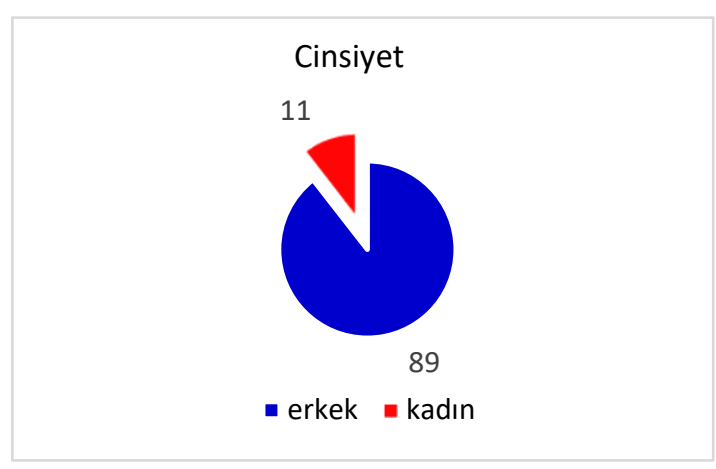

(b)

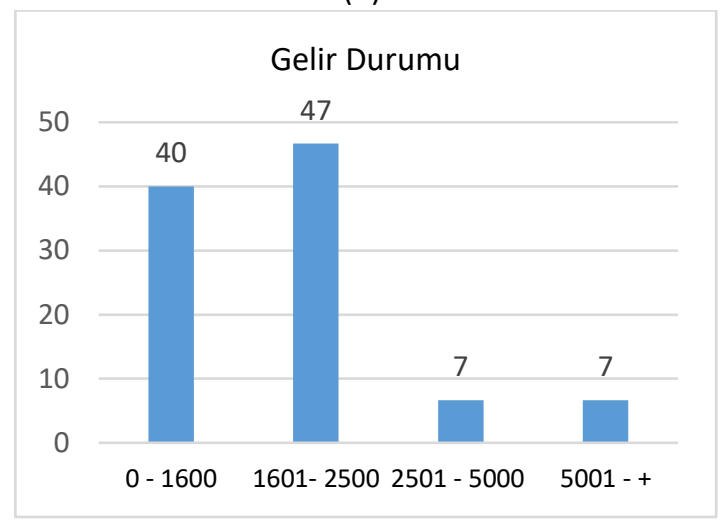

(d)
Şekil 2. Aktarlarla mesleki deneyimleri.

\section{Aktarların ürünleri tedarik etme şekilleri ve yapılan işlemler}

Aktarların aldıkları ürünleri nerelerden tedarik ettikleri, bu ürünleri üretici veya toplayıcıdan aldıktan sonra ne tür işlemler yaptıkları, ürünleri muhafaza şekilleri, ürünlerin

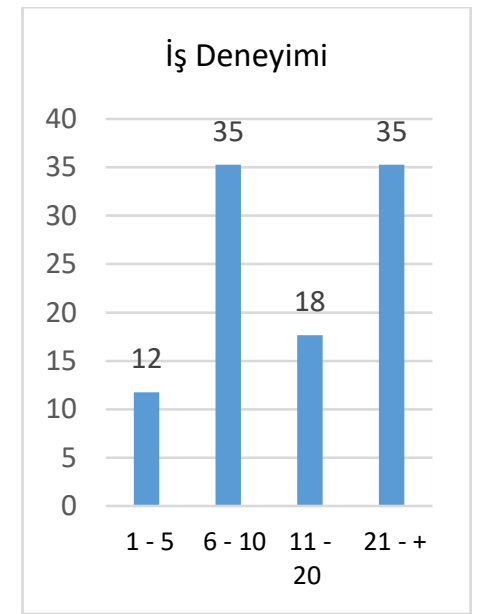

(c) şatış şekilleri ve ürünlerin ortalama satış miktarlarını belirlemek amacıyla sorular sorulmuş bu sorulara alınan cevaplar Şekil 3'de gösterilmektedir. Aktarların ürünleri en fazla satıcı firma ve toptancılardan aldığı, az miktarda da olsa yerel pazarlardan ürün aldığı görülmektedir. Hatay 
ili zengin bir floraya sahiptir. Bu potansiyelinden dolayı bitki toplayıcılığı ve üretimi de fazla miktarda yapılmaktadır. Doğadan toplanan ve üretilen bitkilerin belli bir kısmının aktarlarda satıldığı görülmektedir. Aktarlar üretici veya toplayıcılardan almış olduğu ürünlerde bazı işlemler yaptıklarını

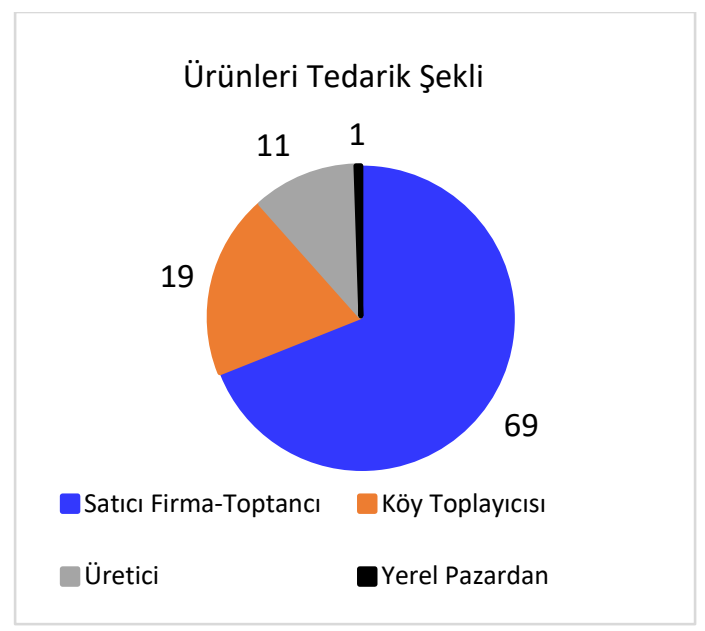

(a)

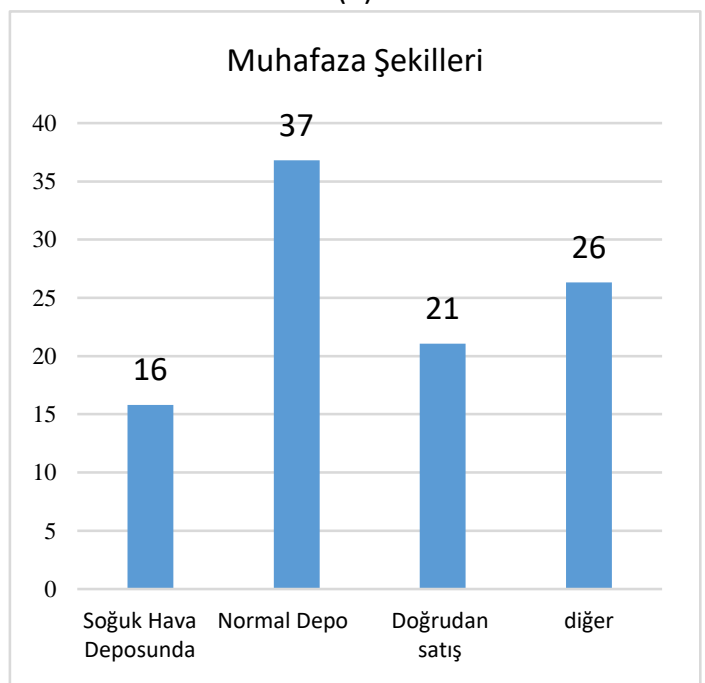

(c)

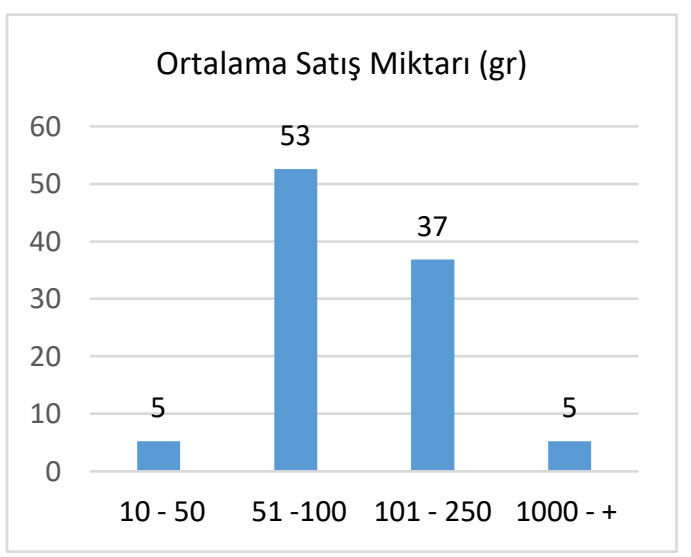

(e) söylemişlerdir. Aktarlar aldıkları ürünlerde en fazla (\%27) temizleme ve ayıklama işlemlerini yaptıklarını belirtmişlerdir. Bunun yanında sınıflandırma, ambalajlama gibi işlemlerin de yapıldığı görülmektedir.

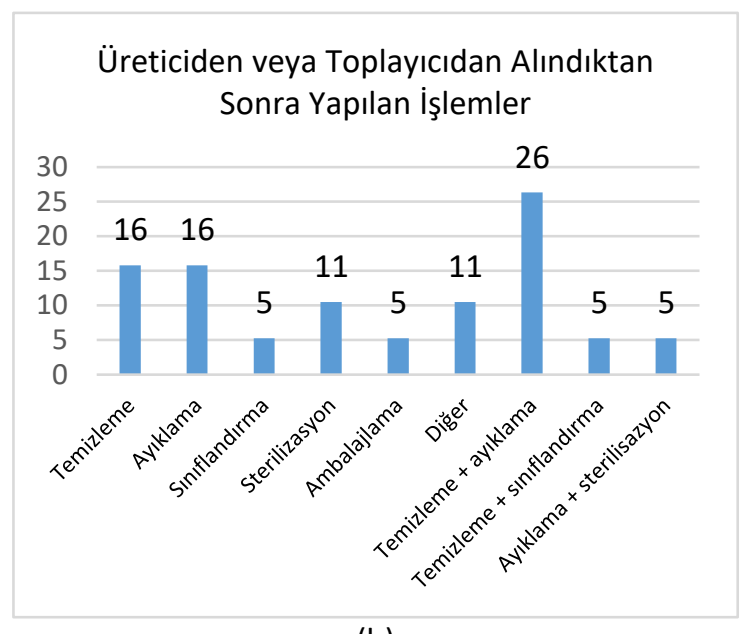

(b)
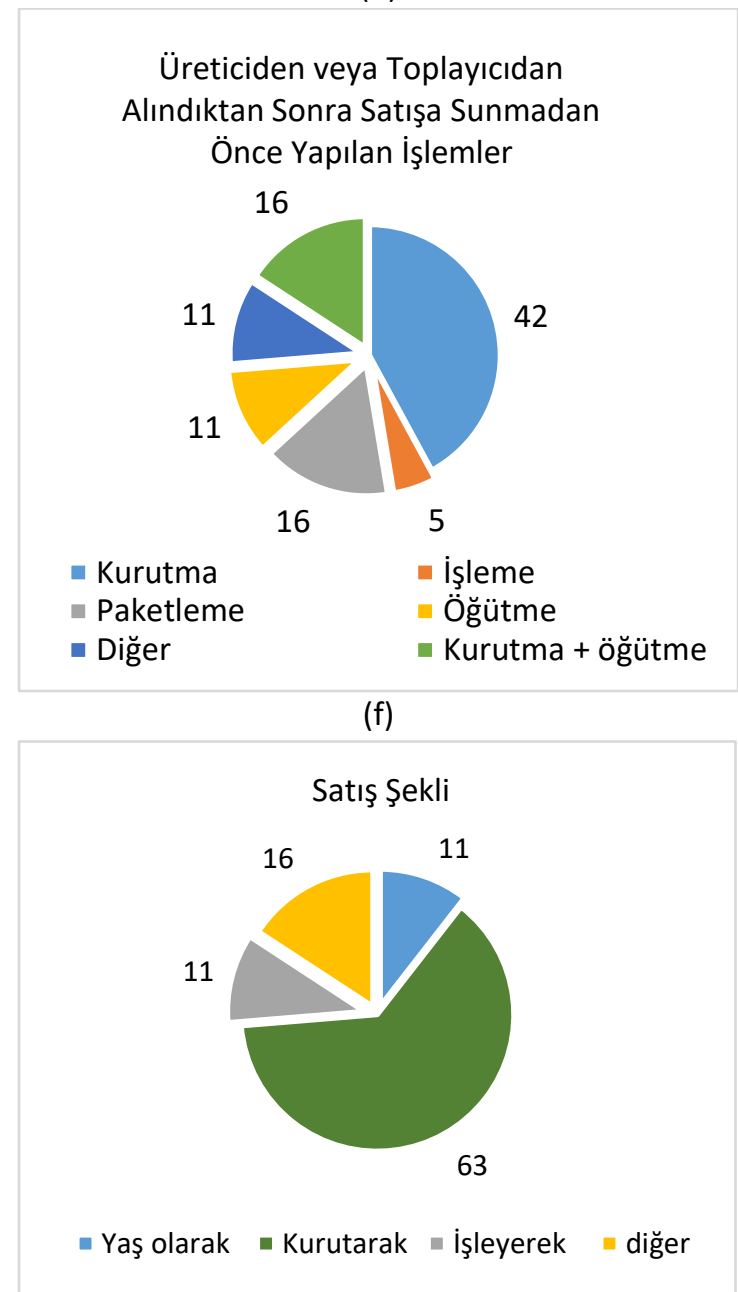

(d)

Şekil 3. Aktarların ürünleri tedarik etme şekilleri ve yapılan işlemler. 
Aktarların ürünleri muhafaza şekilleri incelendiğinde ise \%37'si normal depo sıcaklıklarında herhangi bir soğutma ve ısıtma kullanmadan depolama yaptıklarını belirtmişlerdir. $\% 16$ 'si ise soğuk hava depolarında ürünlerini muhafaza ettiklerini belirtmişlerdir. Aktarlar üretici veya toplayıcılardan aldıktan sonra satışa sunmadan önce bazı işlemler yaptıklarını ve daha çok (\%42) kurutma işlemleri yaptıklarını belirtmişlerdir. Kurutma işlemlerinin yanında paketleme, kurutma ve öğütme, öğütleme gibi işlemleri yaptıktan sonra satışa sunduklarını söylemişleridir. Ürünlerin ağılıklı olarak 51-100 gr arasında satıldığı görülmektedir. Bunu 101-250 gr takip etmektedir. Çok az bir kısmı ise $10-50$ gr ve $1000 \mathrm{gr}$ üzerinde satıldığı görülmektedir. Satışa sunulan ürünlerin daha çok (\%63) kurutularak satıldığı görülmektedir.

\section{Sonuç ve Öneriler}

Son yıllarda hem Dünya da hem de Türkiye de tıbbi ve aromatik bitkiler olan talep artmaktadır. $\mathrm{Bu}$ nedenle tıbbi ve aromatik bitkiler satışı yapan işletmeler de önemli bir hale gelmiştir. Bu işletmelere yönelik yapılan bu araştırmada Hatay ilii Antakya İlçesinde yer alan aktarlarla yüz yüze anket çalışması yapılarak sosyo-ekonomik özellikleri ve satışı yapılan bitkiler belirlenmeye çalışılmıştır.

Aktarların \%89'unun erkek, \%47'sinin 40 yaş üzeri ve \%39'nun lise mezunu olduğu tespit edilmiştir. Katılımcıların \%84'ü mesleği ustasından veya babasından öğrendiğini ve $\% 88^{\prime}$ inin iş deneyimi 6 yıl ve daha fazla olduğu sonucuna ulaşılmıştır. Katılımcıların meslekleriyle ilgili en önemli bilgi kaynaklarının internet ve yazılı kaynaklar olduğu tespit edilmiştir.

Aktarlar satmış oldukları ürünlerin büyük bir bölümünü (\%69) satıcı firma ve toptancılardan, \%30'ünü ise köy toplayıcısı ve üreticilerden aldıkları tespit edilmiştir. Özellikle üretici ve köy toplayıcılarından almış oldukları ürünlerde temizleme, ayıklama, sınıflandırma ve ambalajlama gibi işlemler yapıldığını belirtmişlerdir.

Tıbbi ve aromatik bitkilerin bir çok kullanım şekilleri bulunmaktadır. Aynı bitki tedavi, gıda, baharat ve kozmetik amaçlı kullanılabilmektedir. Kuşburnu bitkisi tedavi amaçlı (\%79) kullanılırken, gıda amaçlı (\%5), baharat (\%5) ve kozmetik(\%5) alanlarında da kullanılmaktadır. Aktarlardan elde edilen bulgulara göre oğul otu (\%89), mercan köşk (\%87) zerdaçal (\%82) daha çok tedavi amaçlı kullanılırken, yaban mersini (\%69), böğürtlen (\%64), reyhan (\%47) gıda olarak kullanılmaktadır. Baharat olarak daha çok defne bitkisi (\%40), çörek otu (\%38) kullanılırken, kozmetik sektöründe daha çok avakado yaprağı (\%25), karaçalı (\%17) ve rezene $(\% 10)$ kullanılmaktadır.
Hatay ilinde tıbbi ve aromatik bitkilerin doğadan bilinçsiz bir şekilde toplanması ve yeterince kültüre alınmamasından dolayı satılan bitkiler genellikle toptancılardan alınmaktadır. Tıbbi ve aromatik bitkilerin üretimi teşvik edildiği takdirde hem aktarcılar hem de tüketiciler daha kolay ve sağlıklı ürünlere ulaşabilir.

\section{Kaynaklar}

Açıkgöz, M.A., Batı, E., Demirkol, G. 2012. Bitkisel tedavi, halk hekimliği ve aktarlar. Tıbbı ve Aromatik Bitkiler Sempozyumu Bildiri Özet Kitabı, 458-461.

Altay, V., Karahan, F., Sarcan, Y.B., İlçim, A. 2015. Kırıkhan ilçesi (Hatay)'nin aktarlarında ve semt pazarlarında satılan bitkiler üzerine etnobotanik bir çalışma. Biological Diversity and Convervations, 8(2): 81-91.

Anonim,2018. http://www.eczacinizadanisin.info/ fitoterapi.pdf (Erişim tarihi: 05.09.2018).

Baytop, T. 1990. Anadolu'da bitkisel drog ticaretinin tarihi. Tarım Orman ve Köyisleri Bakanlığı Dergisi, Sayı: 53, s. 6.

Bayramoğlu, M.M., Toksoy. D. 2008. Aktarlar ve tıbbi bitki ticareti üzerine bir araştırma (Doğu Karadeniz Bölgesi Örneği). TMMOB Orman Mühendisleri Odası Dergisi, Yıl: 45 Sayı: 4-5-6.

Faydaoğlu, E., Sürücüoğlu, M.S. 2011. Geçmişten günümüze tıbbi ve aromatik bitkilerin kullanılması ve ekonomik önemi. Kastamonu Üniversitesi Orman Fakültesi Dergisi, 11(1): 52-67.

Gül, A., Çelik, A.D. 2016. Tıbbi ve aromatik bitki yetiştiriciliği ve dış ticareti: Hatay ili örneği. Mustafa Kemal Üniversitesi Ziraat Fakültesi Dergisi, 21(2): 227-235.

Karagöz, A., Zencirci, N., Tan, A., Taşkın, T., Köksel, H., Sürek, M., Toker, C., Özbek, K. 2010. Bitki Genetik Kaynaklarının Korunması ve Kullanımı. Türkiye Ziraat Mühendisliği VII. Teknik Kongresi, $160 \mathrm{~s}$.

Koçtürk, M.O., Kalafatçılar, Ö.A., Özbilgin, N., Atabay, H. 2009. Türkiye'de bitkisel ilaçlara bakış. Ege Üniversitesi Ziraat Fakültesi Dergisi, 46(3): 209-214.

Ocak, A., Kayıkçı, S., Güzel, Y. 2014. Antakya'nın Doğal Bitkileri Kitabı. 3.

Özbek, H. 2005. Cinsel ve jinekolojik sorunların tedavisinde bitkilerin kullanımı. Van Tıp Dergisi: 12(2): 170-174.

Sarışen, Ö., Çalışkan, D. 2005. Fitoterapi: bitkilerle tedaviye dikkat. Sted Dergisi, 14(8): 182-187.

Tan, A.2010. Türkiye Gıda ve Tarım Bitki Genetik Kaynaklarının Durumu. Gıda ve Tarım için Bitki Kaynaklarının Muhafazası ve Sürdürülebilir Kullanımına İlişkin Türkiye İkinci Ülke Raporu, 12-13. 